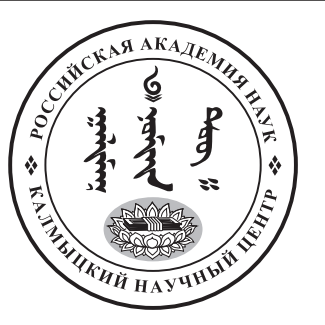

Published in the Russian Federation

Oriental Studies (Previous Name: Bulletin of the Kalmyk Institute

for Humanities of the Russian Academy of Sciences)

Has been issued as a journal since 2008

ISSN: 2619-0990; E-ISSN: 2619-1008

Vol. 14, Is. 3, pp. 479-487, 2021

Journal homepage: https://kigiran.elpub.ru

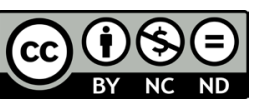

УДК / UDC 94 (470.57)

DOI: $10.22162 / 2619-0990-2021-55-3-479-487$

\title{
Бесхозяйственность и хищения колхозно-кооперативной собственности в колхозах Башкирии в конце 1960-х - первой половине 1980-х гг. как системное явление
}

\section{Наркас Вафиевна Ахмадиева ${ }^{1}$}

${ }^{1}$ Институт истории, языка и литературы Уфимского федерального исследовательского центра РАН (д. 71, пр. Октября, 450054 Уфа, Российская Федерация)

кандидат исторических наук, старший научный сотрудник

iD 0000-0002-5049-6337.E-mail: ahmadieva72@mail.ru

(C) КалмНЦ РАН, 2021

(C) Ахмадиева Н. В., 2021

Аннотация. Введение. В конце 1960-х - середине 1980-х гг. в Башкирии обозначилась тенденция увеличения фактов бесхозяйственности и роста хозяйственно-корыстной преступности в колхозах, что проявлялось в активном хищении социалистической собственности. Исследование данных форм антиобщественного, криминального поведения граждан представляется актуальным. Целью научной статьи является анализ проблем бесхозяйственности и хищений колхозно-кооперативной собственности в колхозах Башкирии в конце 1960-х - первой половине 1980-х гг. Для этого выделено несколько задач: определить виды хищений соцсобственности в колхозах республики, рассмотреть их в динамике; отразить деятельность контрольно-ревизионных органов в колхозах; проанализировать комплексные меры, принятые партийно-государственными и другими контролирующими органами для противодействия росту хозяйственно-корыстной преступности в колхозах. Материаль Национального архива Республики Башкортостан дают детальное представление о динамике роста фактов бесхозяйственности и хищений колхозной собственности в Башкирии, о мерах противодействия этим негативным явлениям. Meтоды исследования. Проблемно-хронологический метод исследования дал возможность проанализировать и выделить проблемы, связанные с сохранностью соцсобственности в сельхозартелях, и мерами, направленными на противодействие хищениям и бесхозяйственности. Принципы объективности и историзма способствовали непредвзятой оценке событий. Результаты. Выявлено, что в исследуемый период, вопреки мерам, принятым властями, во многих колхозах Башкирии имела место преступная бесхозяйственность, шло активное расхищение социалистической (колхозно-кооперативной) собственности. Хозяйственно-корыстные преступления зачастую совершались представителями хозяйственной номенклатуры, имевшей неограниченный доступ к ресурсам. Вывод. В конце 1960-х - середине 1980-х гг. процессы хищений колхозно-кооперативной собственности и бесхозяйственного к ней отношения стали трудноискоренимым системным явлением, усиливая антиобщественные настроения в сельском социуме и обществе в целом. 
Ключевые слова: преступная бесхозяйственность, хищения социалистической собственности, хозяйственно-корыстная преступность, Башкирия в 1960-х - середине 1980-х гг., колхозы Благодарность. Исследование проведено в рамках государственной субсидии - проект «Духовная культура тюркских народов Южного Урала» (номер госрегистрации: АААА-А17-117040350082-3).

Для цитирования: Ахмадиева Н. В. Бесхозяйственность и хищения колхозно-кооперативной собственности в колхозах Башкирии в конце 1960-х - первой половине 1980-х гг. как системное явление // Oriental Studies. 2021. Т. 14. № 3. С. 479-487. DOI: 10.22162/2619-0990-2021-55$3-479-487$

\title{
Mismanagement and Misappropriation of Collective-cooperative Property in the Kolkhozes of Bashkiria between the Late 1960s and the First Half of the 1980s as a Systemic Phenomenon
}

\author{
Narkas V. Akhmadieva ${ }^{1}$ \\ (71, Oktyabrya Ave., 450054 Ufa, Russian Federation) \\ Cand. Sc. (History), Senior Research Associate \\ iD 0000-0002-5049-6337.E-mail: Ahmadieva72@mail.ru \\ (C) KalmSC RAS, 2021 \\ (C) Akhmadieva N. V., 2021
}

${ }^{1}$ Institute of History, Language and Literature of the Ufa Federal Research Centre of the RAS

\begin{abstract}
Introduction. The late 1960s and the first half of the 1980s saw a significant growth of the tendency for mismanagement and misappropriation of socialist property in the kolkhozes (collective farms) of Bashkiria. Such forms of antisocial and criminal behavior of the citizens appears to be a relevant subject. The aim of the present article is to analyze the issues of mismanagement and theft of socialist property in the kolkhozes of Bashkiria in the late 1960s — the first half of the 1980s. In this aspect, several lines of research have been identified: i) to analyze the forms of illegal use of funds and of material values of the farms, examining the phenomena in their dynamics; ii) to examine the work of the control and auditing bodies in the farms; and iii) to analyze a complex of measures taken by the party, state, and other supervisory bodies to counter the growth of economic crimes in kolkhozes. Sources. The archival documents from the National Archive of the Republic of Bashkortostan help to draw a detailed picture of the dynamics in the growth of mismanagement and stealing of collective farm property in Bashkiria, as well as of measures taken to counter these negative phenomena. Methods. The thematic chronological research method proved to be relevant for the analysis and identification of the issues related to the preservation of social property in the farms of Bashkiria, as well as of measures taken by the authorities to stop the facts of misappropriation and mismanagement. The principles of objectivity and historicism applied to a concrete historical situation made it possible to draw a non-partisan picture of the period in question. Results. The research has shown that during the period under study criminal mismanagement in the region took place in many collective farms, accompanied by numerous thefts of socialist property and this happened despite measures taken by the authorities. These crimes were often committed by representatives of the economic nomenclature, who had unlimited access to resources. Conclusion. Between the late 1960s and mid-1980s, the thefts of socialist property and mismanagement events in the collective farms of Bashkiria acquired an intractable systemic character, fostering antisocial sentiments in the rural section and society at large. Keywords: criminal mismanagement, theft of socialist property, economic crime, Bashkiria in the 1960s - mid 1980s, kolkhozes (collective farms)
\end{abstract}

Acknowledgements. The reported study was funded by government subsidy — project name 'Turkic Peoples of the Southern Urals: Spiritual Culture' (state reg. no. AAAA-A17-117040350082-3).

For citation: Akhmadieva N. V. Mismanagement and Misappropriation of Collective-cooperative Property in the Kolkhozes of Bashkiria between the Late 1960s and the First Half of the 1980s as a Systemic Phenomenon. Oriental Studies. 2021. Vol. 14 (3): 479-487. (In Russ.). DOI: 10.22162/26190990-2021-55-3-479-487 


\section{Введение}

В конце 1960-х - первой половине 1980-х гг. в колхозах Башкирии значительно усилились процессы роста бесхозяйственности и хищений колхозно-кооперативной собственности. Следует отметить, что, согласно статье 5 Конституции СССР 1936 г. и статье 10 Конституции СССР 1977 г., основу экономической системы СССР составляла социалистическая собственность на средства производства в форме государственной (общенародной) и колхозно-кооперативной собственности. Никто не вправе был использовать социалистическую собственность в целях личной наживы и в других корыстных целях.

Однако вследствие имевшихся дефектов в организации, планировании и управлении в сфере аграрного производства, а также изза несовершенства системы учета и охраны материально-финансовых ресурсов сельхозартелей эти негативные явления стали весьма распространенными. Они были взаимосвязаны с растущей в данный период в стране хозяйственно-корыстной преступностью. Относительная гуманизация судебно-правовой системы, существенное ослабление, по сравнению со сталинским периодом, методов административного, уголовного и гражданско-правового контроля над сохранностью государственной, общественной, колхозно-кооперативной собственности вызвали увеличение числа корыстных преступлений в сфере народного хозяйства. Так, количество судимостей за хищения государственного имущества в Башкирии возросло в 1966-1971 гг. с 1634 до 1766 случаев, в том числе путем кражи с 876 до 1 113. В пять раз увеличилось число судимостей за хищения государственного имущества в особо крупных размерах [НА РБ. Ф. Р-323. Оп. 4. Д. 8. Л. 82-83].

Целью статьи является исследование проблем бесхозяйственности и хищений собственности в колхозах Башкирии в конце 1960-х - первой половине 1980-х гг. Источниковая база исследования состоит из архивных материалов фондов Национального архива Республики Башкортостан
(НА РБ) и Государственного архива Российской Федерации (ГА РФ), фонда Р-9492 Министерства юстиции СССР. Основные архивные источники, используемые в статье, были выделены из фонда 122 Башобкома КПСС НА РБ. Среди них стенограммы и протоколы заседаний Башкирского обкома КПСС по вопросам усиления борьбы с хищениями социалистической собственности, взяточничеством, спекуляцией; справки о состоянии работы контрольно-ревизионных комиссий в колхозах, сведения по основным показателям работы Министерства внутренних дел Башкирской АССР (далее - БАССР) и т. п. Документальные источники, впервые вводимые в научный оборот, дали четкое представление о развитии элементов бесхозяйственности и росте хозяйственно-корыстных преступлений в колхозах Башкирии исследуемого периода. При анализе архивных источников применялся принцип историзма, объективности, с учетом социально-экономических и общественных процессов, соответствующих данной конкретно-исторической ситуации.

Историография. В 1960-1980-е гг. углубленное внимание проблемам бесхозяйственности и хищений соцсобственности, в силу их криминологической специфики, уделяли ученые-правоведы, пытавшиеся классифицировать эти негативные явления, дать им правовую оценку, выработать действенные меры пресечения правонарушений и преступлений в сфере народного хозяйства [Бородин 1960; Буларгин 1963; Леонтьев 1963; Корноухов 1970; Бабаев, Шляпочников 1979; Ляпунов 1984; Гельфер 1986; Козлов, Осипенко 1988; Ястребов 1983; Кривенко, Чернова 1982].

Среди сугубо исторических работ по проблеме на общероссийском и общесоюзных уровнях следует выделить диссертационное исследование С. В. Богданова, где проведен детальный анализ развития корыстно-хозяйственной преступности в стране в 1945-1990-е гг., включавшей хищения госсобственности путем присвоения, растраты, злоупотребления служебным положением, а также рассмотрены взяточни- 
чество, спекуляция и пр. негативные явления [Богданов 2010].

Интересно и динамично исследован опыт противодействия данным явлениям органами ОБХСС (Отдела по борьбе с хищениями социалистической собственности) в изучаемый период [Тишков, Алабердеев, Латов 2007].

В последние годы историками рассматривались отдельные аспекты проблем борьбы за сохранность соцсобственности в 1940-е гг. [Клинова, Трофимов 2019], особенности хищений государственной собственности в РСФСР 1960-1980-х гг. [Столетова 2019], хищения общественной собственности в послевоенной колхозной деревне Среднего Поволжья [Хасянов 2016].

Проблемы возникновения и развития форм хозяйственно-корыстной преступности при социализме недостаточно отражены в современных исторических работах. Отсутствуют научные труды, посвященные проблемам роста бесхозяйственности и хищений социалистической собственности в колхозах Башкирии в 1960-е - середине 1980-х гг. Фрагментарно данная проблема затрагивалась в ряде научных публикаций, анализирующих рост преступности в республике в указанный период, в том числе рассматривались вопросы развития хозяйственно-корыстной преступности [Ахмадиева 2017а; Ахмадиева 2017б; Ахмадиева, Исянгулов, Сулейманова 2019].

Говоря о росте хищений и фактах бесхозяйственности в колхозах Башкирии указанного периода, следует подчеркнуть, что анализ формирования и функционирования государственной нормативно-правовой базы, направленной на обеспечение сохранности колхозной собственности в союзных и автономных республиках, краях и областях СССР не является целью данной работы. Тем не менее, отметим, что защита колхозно-кооперативной собственности была подтверждена Конституциями 1936 (статьи 5, 7-8) и 1977 гг. (статья 12) и соответствующими статьями гражданско-правового, административно-правового и уголовно-правового кодексов.

В целом на протяжении рассматриваемого периода система мер правового регулирования, нормативно-правового противодействия хищениям колхозно-кооперативной собственности была достаточно жесткой. Уголовный кодекс РСФСР 1960 г. защиту соцсобственности определял как приоритетную задачу и отделял понятия государственной, общественной и личной собственности, причем более жесткое наказание устанавливалось за посягательство именно на социалистическую собственность.

Так, Уголовным кодексом РСФСР 1960 г. (с поправками действовал до конца анализируемого периода) предусматривался ряд мер пресечения преступлений против социалистической собственности, такие как: ст. 89 - хищение государственного или общественного имущества, совершенное путем кражи; ст. 92 - хищение государственного и общественного имущества, совершенное путем присвоения или растраты либо путем злоупотребления служебным положением; ст. 93 - хищение государственного имущества, совершенное путем мошенничества; ст. 93-1 предусматривала наказание вплоть до смертной казни за хищение государственного или общественного имущества в особо крупных размеpax, независимо от способа хищения, - на сумму свыше 10000 руб.; ст. 96 - мелкое хищение государственного или общественного имущества; ст. 99 - неосторожное уничтожение или повреждение государственного или общественного имущества; ст. 100 - недобросовестное отношение к охране государственного или общественного имущества и др. [УК РСФСР 1986: 6573]. Вышеперечисленные статьи Уголовного кодекса РСФСР имеют важное значение в раскрытии проблемы хищений и фактов бесхозяйственного отношения к колхозно-кооперативной собственности в колхозах Башкирии.

\section{Проверка финансово-хозяйственной деятельности колхозов Башкирии в кон- це 1960-х гг. - начале 1970 г.}

Анализ архивных источников из Национального архива Республики Башкортостан наглядно демонстрирует, что в колхозах республики была плохо поставлена ревизионная работа, слабо осуществлялся контроль над соблюдением требований финансовой дисциплины и Устава колхоза. Во многих сельхозартелях ревизии их финансово-хозяйственной деятельности не проводились годами. Ревизионные комиссии своей пас- 
сивностью в отношении бесхозяйственности и расточительства фактически способствовали хищению денежных средств и материальных ценностей в хозяйствах. Административно-управленческие кадры сельхозартелей (председатель, бригадиры, заведующие фермами, заведующие производственными участками, счетно-бухгалтерские работники), обязанные осуществлять контроль над производственными и финансовыми ресурсами колхозов, нередко являлись участниками, либо провоцировали факты бесхозяйственного и хищнического отношения к колхозной собственности.

Осуществленная в 1970 г. органами народного контроля выборочная проверка финансово-хозяйственной деятельности колхозов Башкирии выявила ряд грубых несоответствий в расходовании денежных средств и товарно-материальных ценностей. Финансовые и кассовые операции также осуществлялись с серьезными нарушениями. В 98 сельхозартелях более чем 30 районов (Буздякский, Стерлибашевский, Чишминский, Миякинский и др.) допускались различные злоупотребления, имело место присвоение денежных средств и материальных ценностей [Ахмадиева 2017б: 56-57]. Крупноразмерные, масштабные хищения подрывали экономику аграрного сектора.

В колхозе «Кызыл Чишма» Бакалинского района на конец 1969 г. задолженность подотчетных лиц по авансам составляла 1675 руб., по переполученной зарплате - 4200 руб. Факты бесхозяйственности и нарушения финансовой дисциплины имели место в сельхозартелях Балтачевского, Миякинского, Баймакского, Бижбулякского и других районов. Например, бесхозяйственно расходовались средства в колхозе «Октябрь» Миякинского района на строительство клуба. Так, заработная плата наемным рабочим была выплачена в сумме 103,0 тыс. руб., что составило $64 \%$ от сметной стоимости клуба. Кроме того, по случаю открытия клуба было организовано угощение, на что израсходовали 283 кг птичьего и говяжьего мяса, 900 яиц и других продуктов на сумму 549 руб. На проведение праздника 7 ноября списали продуктов на 145 руб. Значительная сумма денежных средств числилась за колхозниками как долг, в том числе за руководителями колхозов, многие из них задолжали колхозу с 1960 г. В колхозе «Ленинский путь» этого же района образовалась дебиторская задолженность за счет переплат по работе и авансам в сумме более 30,0 тыс. руб. [НА РБ. Ф. 122. ОП. 81. Д. 169. Л. 202-203].

Руководители колхоза им. XXII партсъезда Абзелиловского района необоснованно получили 3648 руб. премии за счет приписок и искажений в отделах о выполнении планов 1969 г. В ряде колхозов нарушался порядок оплаты служебных командировок. В колхозах Бакалинского, Федоровского и других районов выплачивались суточные при поездке руководителей, специалистов и других должностных лиц в районные центры на однодневные совещания, семинары, в отделение Госбанка, в райобъединение «Сельхозтехника»и в другие учреждения. Колхоз «Заря» Калтасинского района, помимо стипендии и заработной платы, незаконно выплатил командировочные специалистам, которые находились на двухмесячных курсах. В 1968-1969 гг. колхоз реализовал продукции на сумму 71,1 тыс. руб., из этой суммы израсходовали 52,0 тыс. руб. на разные цели, минуя Госбанк [НА РБ. Ф. 122. Оп. 81. Д. 169. Л. 204].

Столь многочисленные факты незаконного использования денежных средств и материальных ценностей колхозов явились следствием индифферентного отношения партийно-хозяйственной номенклатуры к общественной собственности, этой отрицательной и тревожной тенденции в развитии советского общества. В ряде случаев счетно-бухгалтерские работники вполне сознательно злоупотребляли служебным положением. В среде хозяйственной номенклатуры, имевшей доступ к финансовым и материальным средствам сельхозартелей, создавались предпосылки для возникновения коррупции.

Рост бесхозяйственности и хищений социалистического имущества в сельхозартелях Башкирии в 1970-е - первой половине 1980-х гг.

В докладе первого секретаря Башобкома КПСС М. 3. Шакирова на собрании республиканского партийного актива 14 июля 1972 г. отмечалось, что отдельные работники из корыстных, карьеристских побуждений, не желая признать допущенные про- 
счеты, шли на обман государства, допуская «приписки и очковтирательство». За 19681972 гг. в ряде сельских районов (Гафурийском, Благоварском, Калтасинском, Янаульском, Дуванском, Стерлитамакском и др.) число преступных проявлений возросло. В них не проводилась предупредительная работа, отсутствовало моральное осуждение антиобщественных поступков в трудовых коллективах. Значительные потери несли от бесхозяйственности, отсутствия должного контроля и ответственности отдельные колхозы и совхозы. За 1971 г. был допущен падеж крупного рогатого скота 3,6 \% к обороту стада, свиней $-9 \%$ и овец $-9,5 \%$. В то же время возмещено за счет виновных было лишь 5,2 \% причиненного ущерба. Руководство Башкирии потребовало усилить внимание административных органов и хозяйственных руководителей в данном вопросе, добиваться устранения причин, порождающих бесхозяйственность, строго взыскивать с тех, кто своей безответственностью наносил ущерб государству [НА РБ. Ф. 122. Оп. 185. Д. 133. Л. 57-60].

Правоохранительные органы республики принимали определенные меры по пресечению фактов хищений соцсобственности. В 1974 г. в сельском хозяйстве Башкирии было выявлено 189 случаев хищений на сумму в 94,2 тыс. руб., возмещение ущерба составило всего лишь $76,6 \%$ от его суммы. В том числе в колхозах выявили 113 случаев хищений на сумму 72,8 тыс. руб., с 78,4-процентным возмещением ущерба [НА РБ. Ф. 122. Оп. 189. Д. 303. Л. 19-20]. Следует отметить, что середина 1970-х гг. в республике обострила рост корыстных преступлений в общей структуре преступности. В 1976 г. по ст. 92 Уголовного кодекса (хищение путем присвоения и растраты, либо злоупотребления служебным положением) были осуждены 430 чел., в том числе к 95 (22,1 \%) подсудимым применили меру наказания в виде лишения свободы. За мелкое хищение осудили 786 чел., из них только 244 (31 \%) были приговорены к лишению свободы [НА РБ. Ф. 122. Оп. 190. Д. 348. Л. 5]. В целом по России удельный вес осужденных по данной статье оставался достаточно стабильным. Так, в 1976 г. он составил 19,2\%, в 1982 г. - 19,1 \% к общему числу осужденных за хищения [ГА РФ. Ф. Р-9492. Оп. 6. Д. 375. Л. 45].
В противодействии росту хищений соцсобственности большое значение придавалось деятельности Отдела борьбы с хищениями социалистической собственности и спекуляцией (ОБХСС), созданного в 1937 г. при Наркомате внутренних дел СССР. В 1975 г. принятые правительственные постановления, направленные на защиту социалистического (государственного, общественного) имущества, заметно улучшили функционирование данной правоохранительной структуры. В 1975-1976 гг. операция «Урожай» выявила порядка 17 тыс. фактов правонарушений и преступлений, аграрной отрасли вернули различной продукции на сумму около 2 млн руб. [Тишков, Алабердеев, Латов 2007: 69-70]. Бесхозяйственность и хищения соцсобственности как негативные явления советской экономики присутствовали во всех отраслях народного хозяйства страны, что подтверждало их системный характер.

В условиях нарастания масштабов хозяйственно-корыстных преступлений в стране, власти прибегли к помощи общественности, расширив деятельность органов народного контроля. В январе 1980 г. правительство приняло меры, направленные на улучшение деятельности данной организации. Особое значение придавалось моральным и идейным качествам народных контролеров, более одной трети которых составляли члены партии [НА РБ. Ф. 122. Оп. 200. Д. 56. Л. 10-11].

Рядовые колхозники, сознательные граждане писали письма, обращались во власть с требованиями усилить контроль над растущими антиобщественными проявлениями, бесхозяйственностью и экономическими преступлениями. Письма из Аскинского, Бижбулякского, Ишимбайского, Кугарчинского, Шаранского районов указывали на недостатки в деятельности сельскохозяйственных органов, упущении в планировании, вскрывались факты нерадивого отношения к государственной и общественной собственности, бесхозяйственности. Актуализировались вопросы наказания лиц, причастных к хищениям государственной и общественной собственности, допускающих злоупотребления служебным положением. В связи с этим Прокурору БАССР, министру внутренних дел было предписано усилить охрану правопорядка в городах и сельских 
населенных пунктах, сконцентрироваться на имеющихся сигналах, оперативно устранять нарушения в этом деле [НА РБ. Ф. 122. Оп. 206. Д. 143. Л. 2-7].

Несмотря на совместные усилия партийно-государственных, правоохранительных, хозяйственных органов, хозяйственно-корыстная преступность в республике продолжала набирать обороты. Налицо были факты коррумпированности некоторых представителей правоохранительных структур. В 1983 г. в республике были вскрыты факты посягательств на социалистическую собственность, бесхозяйственности, взяточничества и спекуляции. За хищения были привлечены к уголовной ответственности ряд номенклатурных и хозяйственных работников аграрной отрасли [НА РБ. Ф. 122. Оп. 209. Д. 4. Л. 23-25].

Для более полного возмещения экономического ущерба прокуратура БАССР активизировала применение гражданско-правовых средств. Суды республики также ужесточили меры наказания по делам о хищениях соцсобственности в виде конфискации имущества, лишения права занимать руководящие, материально ответственные должности. В 1983 г. меру наказания в виде лишения свободы применили к 41,5 \% подсудимым. В судах рассмотрели 226 исков и возместили 252 тыс. руб.; у более половины осужденных произвели конфискацию имущества. Возросла доля судебных исков о возмещении ущерба от нерационального использования топливно-энергетических ресурсов, разукомплектования и порчи сельхозтехники, грубых нарушений правил техники безопасности и т. п. [Ахмадиева 2017a: 59].

Несмотря на принимаемые комплексные меры в отношении роста хозяйственно-корыстных преступлений, хищений соцсобственности в аграрном секторе, снизить масштабы данных негативных процессов не удавалось. В 1984 г. в отдельных колхозах и совхозах Башкирии продолжились хищения, недостачи, порча материальных ценностей, случаи небрежного отношения к сельскохозяйственной технике. Гибель общественного скота причиняла значительный ущерб некоторым хозяйствам. Наиболее серьезные нарушения законов об охране социалистической собственности допускались в колхозах и совхозах Аскинского, Баймакского, Белокатайского, Бижбулякского, Га- фурийского, Караидельского, Краснокамского, Мечетлинского районов. Так, в хозяйствах Баймакского района в 1983 г. была допущена недостача материальных ценностей на 128 тыс. руб., ущерб от гибели скота оценивался на сумму 1371 тыс. руб. Колхозы и совхозы Мечетлинского района допустили падеж скота на 506 тыс. руб. Вследствие ненадлежащей подготовки помещений к зимовке скота в колхозе «Заря» Белокатайского района от простудных заболеваний пало 228 голов свиней, чем хозяйству причинен убыток на сумму 5377 руб. [НА РБ. Ф. 122. Оп. 212. Д. 120. Л. 18-25]. Объемы ущерба существенно возрастали, принимаемые меры противодействия распространению бесхозяйственности и хищения соцсобственности работали очень слабо.

\section{Заключение}

В конце 1960-х - первой половине 1980-х гг., несмотря на все принимаемые партийно-государственными органами меры, во многих колхозах Башкирии имела место бесхозяйственность, происходило активное хищение колхозно-кооперативной собственности. Это было связано с существующими изъянами в самой системе общественного (планового) хозяйства сельхозартелей. Так, система учета, хранения и расходования ресурсов аграрной отрасли находилась не на должном уровне. Антиобщественное поведение ряда руководителей сельхозартелей, местных партийных, советских, контрольно-ревизионных органов, которые не только не противодействовали нерадивому отношению к соцсобственности, попустительствовали развитию хищений и бесхозяйственности, но зачастую сами совершали хозяйственно-корыстные преступления, способствовало формированию негативных установок у части рядовых колхозников.

Общественность Башкирии слабо привлекалась к обеспечению сохранности народного достояния. Процессы разворовывания колхозной собственности, бесхозяйственного отношения к «народному добру» затрагивали все слои сельского сообщества, формируя девиантное поведение у части населения. Бесхозяйственность и хищение социалистической собственности были системными, трудноискоренимыми явлениями, негативными издержками советской действительности. 


\section{Источники}

ГА РФ - Государственный архив Российской Федерации.

НА РБ - Национальный архив Республики Башкортостан.

\section{Литература}

Ахмадиева 2017а - Ахмадиева Н. В. Экономические девиации в советском обществе (на примере БАССР 1960-х - начала 1980-х гг.) // Социальные девиации в советском обществе: региональный аспект (на примере Башкирской АССР 1960-х - начала 1980-х гг.): Сб. ст. Уфа: ИИЯЛ УНЦ РАН, 2017. C. 47-64.

Ахмадиева 2017б - Ахмадиева Н. В. Экономическая преступность в Башкирии в 1960-е - начале 1980-х гг. // Вестник Оренбургского государственного педагогического университета. 2017. № 4 (24). C. 54-66. DOI: 10.32516/2303-9922

Ахмадиева, Исянгулов, Сулейманова 2019 - $A x$ мадиева Н. В., Исянгулов Ш. Н., Сулейманова Р. Н. Асоциальные явления в общественной жизни Башкирии в 1960 - начале 1980-х годов // Вестник Академии наук Республики Башкортостан. 2019. Т. 32. № 3 (95). С. $65-$ 73. DOI: $10.24411 / 1728-5283-2019-10308$

Бабаев, Шляпочников 1979 - Бабаев М. М., Шляпочников A. C. Экономические факторы в механизме преступного поведения // Советское государство и право. 1979. № 2. C. $60-67$.

Богданов 2010 - Богданов С. В. Хозяйственно-корыстная преступность в СССР 19451990-е гг.: факторы воспроизводства, основные показатели, особенности государственного противодействия: автореф. дисс. ... д-ра ист. наук. Курск, 2010. 50 с.

Бородин 1960 - Бородин С. В. Из практики судов РСФСР по рассмотрению дел о растратах и хищениях социалистической собственности // Советское государство и право. 1960. № 6. C. 111-116.

Буларгин 1963 - Буларгин В. Борьба с хищениями социалистической собственности в сельском хозяйстве, совершаемыми путем приписок // Социалистическая законность. 1963. № 1. С. 33-36.

Гельфер 1986 - Гельфер М. А. Хозяйственные преступления: Уч. пособ. М.: ВЮЗИ, 1988. $56 \mathrm{c}$.

Клинова, Трофимов 2019 - Клинова М. А., Трофимов A. B. «Установить строжайший кон-
Sources

National Archive of the Republic of Bashkortostan. State Archive of the Russian Federation.

троль за сохранностью социалистической собственности»: кампания по борьбе с хищениями во второй половине 1940-х гг. // Гуманитарные науки в Сибири. 2019. № 1. C. $82-86$.

Козлов, Осипенко 1988 - Козлов Ю. Г., Осипенко $O . B$. Недостатки материально-технического снабжения и хозяйственно-корыстная преступность // Советское государство и право. 1988. № 6. С. 78-85.

Корноухов 1970 - Корноухов В. Е. Планирование расследования преступлений по делам о хищении колхозного имущества, совершаемого путем присвоения или растраты либо путем злоупотребления служебным положением // Ученые записки Саратовского юридического института имени Д. И. Курского. Сборник работ соискателей и аспирантов. Саратов: Изд-во Сарат. юрид. ин-та, 1970. Вып. 19. Ч. 1. С. 288-295.

Кривенко, Чернова 1982 - Кривенко Т. Д., Чернова К. Т. Преступная бесхозяйственность и ее предупреждение // Советское государство и право. 1982. № 12. 1982. С. 76-84.

Леонтьев 1963 - Леонтьев Б. М. Ответственность за хозяйственные преступления. М.: Госюриздат, 1963. 192 с.

Ляпунов 1984 - Ляпунов Ю. И. Хищение как форма преступного использования служебного положения // Советское государство и право. 1984. № 10. 1984. С. 95-102.

Столетова 2019 - Столетова А. С. Особенности хищений государственной собственности в РСФСР 1960-1980-х годов // Научный диалог. 2019. № 12. С. 379-391. DOI: 10.24224/2227-1295-2019-12-379-391

Тишков, Алабердеев, Латов 2007 - Тииков С. В., Алабердеев Р. Р., Латов Ю. В. История борьбы в СССР с хищениями социалистической собственности (к 70-летию ОБХСС / ДЭБ) // Историко-экономические исследования. 2007. № 1. Т. 8. С. 51-80.

УК РСФСР 1986 - Уголовный кодекс РСФСР. М.: Юрид. лит. 1986. 191 с.

Хасянов 2016 - Хасянов О. Р. Хищение общественной собственности в послевоенной колхозной деревне: от стратегии крестьянского повседневного сопротивления // 
Вестник Самарского университета. История, педагогика, филология. 2016. № 1 . C. 63-69.

\section{References}

Akhmadieva N. V. Economic crimes in Bashkiria in the 1960s - early 1980s. Vestnik of Orenburg State Pedagogical University. Electronic scientific journal. 2017. No. 4 (24). Pp. 54-66. DOI: 10.32516/2303-9922 (In Russ.)

Akhmadieva N. V. Economic deviations in Soviet society: a case study of the Bashkir ASSR, 1960s - early 1980s). In: Akhmadieva N. V. (ed.) Social Deviations of Soviet Society in a Regional Perspective: A Case Study of the Bashkir ASSR, 1960s - early 1980s. Collected papers. Ufa: Institute of History, Language and History (Ufa Federal Research Centre of RAS), 2017. Pp. 47-64. (In Russ.)

Akhmadieva N. V., Isyangulov Sh. N., Suleimanova R. N. Anti-social phenomena in the public life of Bashkiria in the 1960s - early 1980s. Herald of the Academy of Sciences of the Republic of Bashkortostan. 2019. Vol. 32. No. 3 (95). Pp. 65-73. DOI: 10.24411/1728-5283-201910308 (In Russ.)

Babaev M. M., Shlyapochnikov A. S. Economic factors in the mechanism of criminal behavior. Soviet State and Law. 1979. No. 2. Pp. 60-67. (In Russ.)

Bogdanov S. V. Economic Crimes in the USSR, 1945-1990s: Factors of Reproduction, Key Indicators, Features of State Resistance. Dr. Sc. (history) thesis abstract. Kursk, 2010. 50 p. (In Russ.)

Borodin S. V. Mismanagement and embezzlement of socialist property: glimpses of RSFSR court practices. Soviet State and Law. 1960. No. 6. Pp. 111-116. (In Russ.)

Bulargin V. Struggling against figure falsification thefts of socialist property in agriculture. Sotsialisticheskaia zakonnost'. 1963. No. 1. Pp. 33-36. (In Russ.)

Criminal Code of the RSFSR. Moscow: Yuridicheskaya Literatura, 1986. 191 p. (In Russ.)

Gelfer M. A. Economic Crimes. Moscow: AllUnion Correspondence University of Law, 1988. 56 p. (In Russ.)
Ястребов 1983 - Ястребов В. Б. Причины хищений социалистического имущества // Советское государство и право. 1983. № 8. С. 81-89.

Khasyanov O. R. Theft of public ownership in the postwar collective farms: from the strategy of peasant resistance to routine tactics devices. Vestnik of Samara University. History, Pedagogics, Philology. 2016. No. 1. Pp. 63-69. (In Russ.)

Klinova M. A., Trofimov A. V. 'Establish strict control over the safety of socialist property': campaign against embezzlements in the second half of the 1940s. Humanitarian Sciences in Siberia. 2019. No. 1. Pp. 82-86. (In Russ.)

Kornoukhov V. E. Embezzlement of collective farm property via misappropriation or abuse of official position: planning investigations of crimes. In: Kursky Saratov Institute of Law. Scientific Notes. Collected papers. Saratov: Saratov Institute of Law, 1970. Vol. 19. Part 1. Pp. 288-295. (In Russ.)

Kozlov Yu. G., Osipenko O. V. Deficits in material and technical supply and economic crime. Soviet State and Law. 1988. No. 6. Pp. 78-85. (In Russ.)

Krivenko T. D., Chernova K. T. Criminal mismanagement and its prevention. Soviet State and Law. 1982. No. 12. Pp. 76-84. (In Russ.)

Leontiev B. M. Responsibility for Economic Crimes. Moscow: Gosyurizdat, 1963. 192 p. (In Russ.)

Lyapunov Yu. I. Theft as a form of criminal abuse of official position. Soviet State and Law. 1984. No. 10. 1984. Pp. 95-102. (In Russ.)

Stoletova A. S. Specifics of theft of state property in the RSFSR of 1960s-1980s. Scientific Dialogue. 2019. No. 12. Pp. 379-391. DOI: 10.24224/2227-1295-2019-12-379-391 (In Russ.)

Tishkov S. V., Alaberdeev R. R., Latov Yu. V. History of struggle against thefts of socialist property in the USSR: celebrating the $70^{\text {th }}$ anniversary of the OBKhSS and Economic Security Department. Journal of Economic History and History of Economics. 2007. Vol. 8. No. 1. Pp. 51-80. (In Russ.)

Yastrebov V. B. Causes of socialist property thefts. Soviet State and Law. 1983. No. 8. Pp. 81-89. (In Russ.) 